\title{
TXNRD1 wt Allele
}

National Cancer Institute

\section{Source}

National Cancer Institute. TXNRD1 wt Allele. NCI Thesaurus. Code C107617.

Human TXNRD1 wild-type allele is located within 12q23-q24.1 and is approximately 135 $\mathrm{kb}$ in length. This allele, which encodes thioredoxin reductase 1, cytoplasmic protein, is involved in the modulation of oxidative stress. 